\title{
Development of Information
}

\section{Technology Competences}

\section{at the University as a Place}

of Scientific Research and of Education of Intellectual Elites

\section{Mateusz Muchacki}

\begin{abstract}
Contemporary times make every person, including an academic teacher, face challenges concerning the application of modern media tools in professional work, especially the use of the Internet to increase the effectiveness and the quality of his/her professional activity. The author draws attention to the necessity of a significant change in the system of academic education to help academic teachers handle modern teaching requirements. Teaching at the university level should take into account state-of-the-art tools of the teaching technology supporting the student's general development, his/ her information technology skills as well as the formation of innovative and creative attitudes, preparing them to many new professional actions (including ICT).
\end{abstract}

Key words: Information technology competences, information society, academic education 


\title{
Rozvíjení schopnosti práce s digitálními technologiemi na Univerzitě jako místě pro vědecký výzkum a vzdělávání intelektuálních elit
}

\begin{abstract}
Dnešní doba staví výzvy před každým člověkem - také před vysokoškolským učitelem. Tyto výzvy se týkají moderního mediálního instrumentária v profesní práci, obzvláště pak využití internetu ke zvyšování efektivity a kvality jeho profesních činností. Autor v textu upozorňuje na nutnost zavedení podstatných změn ve vysokoškolském vzdělávání, staví před vysokoškolskými učiteli požadavky moderního vzdělávání. Didaktika vysoké školy by měla zohledňovat aplikaci nejnovějších nástrojů technologie vzdělávání a napomáhat tak celkovému vývoji studenta, jeho samostatného uvažování, schopnosti práce s digitálními technologiemi a utváření inovativního a kreativního postoje a připravovat ho na mnoho nových profesních činností.
\end{abstract}

Klíčová slova: ICT kompetence, informační společnost, vysokoškolské vzdělávání

Referring to P. F. Drucker's thought - it can be emphasized that the University, like "each organization (institutions), should now have one key competence: innovativeness" (Drucker, 2010, p. 137), regardless of the type of the industrial sector or the service area, as long as it intends to achieve success in the contemporary and, at the same time, diverse job market.

The contemporary job market, which also exists today in the media time and space as well as in the information technology time and space, makes every person, including an academic teacher, face challenges concerning the application of modern media tools in professional work, especially the use of the Internet to increase the effectiveness and the quality of professional activity. Thus, these challenges require the acquisition of information technology competences, such as:

[a] proficiency in the application of IT tools,

[b] becoming familiar with the application of information technology in various areas of life and in professional work,

[c] integration of the uses of information technology with various spheres of existence and with various areas of professional (occupational) activity and

[d] specialization in the application of knowledge on computer science and information technology (Sysło, 2010). The acquisition of IT competences should be a continuous educational process which ought to be implemented both at primary school (the place of education in the area of key competences) as well as at the university (as a place of scientific research and education of intellectual elites). 
Two books which could be called heralds of the birth of network society or perhaps society from the era of information technology (media civilization) were published over the years. These books are: "Computerspiele in der Kinderkultur" (Fromme, Meder, Vollmer, 2000) and "Children and Their Changing Media Environment" (Fromme, Meder, Vollmer, 2000). The authors of the former - J. Fromme, N. Meder and N. Vollmer, showed and proved at the same time that virtual worlds "exist" in the life of contemporary people since their childhood. Therefore, today we can talk both about children's computer games (Computerspiele) (Fromme, Meder, Vollmer, 2000), as well as children's culture of computer games (Computerspielkulturen) (Fromme, Meder, Vollmer, 2000). Aditionally, in the other publication which is a joint publication, edited by S. Livingstone and M. Bovill, some authors, including: J. W. J. Beentjes, C. M. Koolstra, N. Marseille, T. H. A. van der Voort, S. Livingstone, showed the existential activity of the contemporary child in the area of the media (Fromme, Meder, Vollmer, 2000) - mostly in two periods - of mid and late childhood.

Careful observation of the contemporary job market as well as of its needs and expectations allows for drawing a prudent conclusion that primary schools, secondary schools and universities - both in Poland and other EU countries - cannot keep up with dynamic changes connected with the development of modern information and communication technologies. The new media, omnipresent in the contemporary time and space, require the knowledge of the "language of numerical data" (Manovich, 2006, p. 82) and they must be an object of educational and scientific processes. The new media are the basic tool of professional activity of a large number of people and, more importantly, a tool of intellectual work for people employed at universities and various scientific institutions. In the context of contemporary media convergence, which in reality seems to be convergence of thoughts/thinking processes resulting from interpersonal relations / from social interactions between media users (Jenkins, 2007, p. 9), media education and upbringing for the media seem to be necessary. Media education appears to be the fundamental source for acquiring information technology competences and media competences in the contemporary world. A. Serdyński (2007, p. 43), while writing about a teacher's information and media competences (also including the academic teacher) distinguishes:

[1] in the area of information science competences:

[a] instrumental information technology competences and

[b] directional information technology competences, as well as

[2] in the area of media competences:
[a] theoretical media competences,
[b] pedagogical media competences,
[c] teaching media competences and
[d] personal media competences. 
The aforementioned classification of the teacher's information technology and media competences became my inspiration for an attempt to present my own model of information technology and media competences necessary in the work and life of the contemporary academic teacher. Therefore, it can be assumed that an academic teacher (as an active member of information technology civilization) should posses:

[1] basic information technology competences i.e. practical skills of using resources and information technology tools in everyday life and, in particular, in scientific activity/ professional work

and

[2] basic media competences i.e. theoretical knowledge on the influence of the media on the development of personality, as well as basic practical skills - in the area of operation of various contemporary media.

In the area of an academic teacher's basic information technology competences, two spheres of competences can be distinguished:

[a] technical information technology competences and

[b] professional information technology competences.

Technical information competences of each contemporary European should be obligatorily developed as soon as possible, already during secondary school education and should (in my opinion) obligatorily include the following technical activities:

[a] the ability to operate the Windows operating system exploration of basic Windows applications, management of files and folders, Desktop configuration, installation and removal of programs;

[b] the ability to operate the Word text editor creating a document, changing the form (appearance) of the text in the document, changing the form (appearance) of the document, printing the document, presenting the information in the document in the form of tables and columns, inserting graphics (graphic materials) in the text in the document, creating charts;

[c] the ability to search for information on the Internet - exploration of the Internet network, looking for information using popular internet browsers - together with the ability to use electronic mail;

[d] the ability to use available services in the information technology network; and

[e] the ability to create presentations using applications which are made available with the ability to create graphics for presentations;

[f] the ability to design websites.

Without the achievement of these technical information technology competences it is difficult to talk about an academic teacher as a member of society of information 
technology era called information society (Global Information society), which has recently come to be called: information and knowledge society. These concerns are confirmed by data contained in the EuroStat report published in 2005 (Reis, za: Chmielarz, 2007, p. 280) indicating a clear distance of European Union citizens towards relations with public administration through the e-government system, as, for example - only $18.0 \%$ of Danish people used basic administrative (public) services through the e-government system, and this percentage percentage was even lower in other countries - for example, it amounted to $17.0 \%$ of all inhabitants in Spain, 16.0\%, in Austria, 14.0\% in Finland, $14.0 \%$ in Sweden, $11.0 \%$ in Germany and, finally $5.0 \%$ in Great Britain. It seems very likely, however, that these data primarily present a lack of these technical information technology competences in a majority of European Union citizens who completed their education in the last century.

While writing about data from the EuroStat, I am aware that this distance of European Union citizens to relations of citizens with public administration through the e-government system may result from sociocultural attitudes which currently predominate in European society, resulting from the existing "traditional" knowledge, ideology, hierarchy of values and, primarily, both existing social customs and lack of knowledge in experience in information culture. Data concerning this knowledge and experience in intellectual elites would be interesting. Now, however, I would like to return to the problems of professional information competences.

Professional information technology competences include various information technology activities, which mostly depend on the character/type of professional activity of a given person, as competences required in the e-commerce sector differ from those needed in e-learning or e-medicine. It should be emphasized that currently the professional ability to design websites nearly in all industrial branches and in service sectors leaves a lot to be desired and must often be unambiguously evaluated as: unsatisfactory. One could quote here various examples exposing to ridicule authors of fashionable presentations (also among intellectual elites) which contain diverse blatant errors, as well as the authors of numerous other websites, who present their product only for marketing purposes, as well as authors of commercials and information at websites of numerous institutions (also scientific ones) which create these websites in an unprofessional manner.

Professional information technology competences must include not only: [a] the ability to create presentations using available applications together with the skill of creating graphics to be used in such a presentation, [b] the ability to design websites, but also [c] proficient and correct knowledge of grammar (and in particular spelling) of one's native language and [d] broad professional knowledge concerning the professional object. Unfortunately, today professional competences are nearly only those which ensure a high profit. Also, professional information technology competences seem to be profit- 
oriented. Despite these "drawbacks", we are now aware that both the development of public electronic administration systems, as well as the development of systems strengthening e-business in the contemporary world, are irreversible phenomena which unambiguously herald the era of Information and Knowledge, which will have its actual beginning only in the future.

The acquisition of information competences today, before the arrival of the Information and Knowledge era, the era of the "numerical data language", is certainly a condition for proper existence of a contemporary academic teacher in the world of common presence of the media. Information tools to be used for work by people in the contemporary time and space must be "transparent" for them. Moreover, both the process of creating information, and the process of receiving information, are complex intellectual activities and, as such, they require appropriate information technology competences in the intellectual and cultural aspect. Perhaps, it is worth thinking about the issue of distinguishing various types of these competences, such as children's information technology competences (Grochowalska, 2010), parents' information technology competences, teachers' information technology competences, academic teachers' information technology competences, tourist service employees' information technology competences, business employees' information technology competences, e-medicine information technology competences etc., and finally - information technology competences of the contemporary person.

Nowdays, everybody accepts civilization changes, however, in my opinion one should assess negatively the level of society's awareness in the area of the necessity of broadening knowledge and experience allowing for obtaining necessary information technology competences. Contemporary times require significant changes in the academic education system and they make academic teachers face new tasks and requirements of modern education. Teaching at the university level should take into account state-of-the-art tools of the teaching technology supporting the student's general development (Czaja-Chudyba, 2013) his/her information technology skills, as well as the formation of innovative and creative attitudes, preparing them to many new professional actions (including ICT). It should be remembered that student achievements largely depend on the quality of teaching, and namely, on the level of the teachers' work and on educational centres of a given university.

Referring to the authority of W. Chmielarz (2007) ${ }^{1}$ - attention should be paid to the fact that socioculturural conditions for contemporary civilization changes now leading humanity to the birth of Information and Knowledge Society are not noticed frequently, and sometimes, they are neglected by the creators of virtual organizations, despite the fact that these virtual undertakings require significant changes at various levels in

Prof. Witold Stefan Chmielarz is an academic teacher of long standing at the Faculty of Management, University of Warsaw, and the author of commonly known monographs: Systemy elektronicznej bankowości, Warszawa 2005 and: Systemy biznesu elektronicznego, Warszawa 2007. 
human attitudes "starting from qualifications, skills through (...) motivation to the way of thinking and perceiving the surrounding reality" (2007, p. 297). On the other hand, the aforementioned changes in human attitudes, concerning a positive attitude towards the new media and towards the information technologies require both knowledge and experience.

\section{References}

Beentjes, J. W. J., Koolstra, C. M., Marseille, N. \& Van der Voort, T. H. A. (2001). Children's Use of Different Media. In Livingstone, S. M., \& Bovill, M. Children and their changing media environment: A European comparative study. Mahwah, N.J: L. Erlbaum.

Chmielarz, W. (2005). Systemy elektronicznej bankowości. Warszawa: Centrum Doradztwa i Informacji “Difin”.

Chmielarz, W. (2007). Systemy biznesu elektronicznego. Warszawa: Centrum Doradztwa i Informacji "Difin".

Czaja-Chudyba, I. (2013). Myślenie krytyczne w kontekstach edukacji wczesnoszkolnej - uwarunkowania nieobecności. Kraków: Wyd. Naukowe UP.

Drucker, P. F. (2010). Zarządzanie [in] XXI wieku: Wyzwania, series: >Klasyka Biznesu<, Warszawa: Muza.

Fromme, J., Meder, N., \& Vollmer, N. (2000). Computerspiele in der Kinderkultur. Opladen: Leske + Budrich.

Grochowalska, M. (2010). Przekaz medialny w rozwoju i edukacji dzieci. In: Smak, E. \& Włoch, S. Pedagogika kreatywna wyzwaniem edukacji XXI wieku. Opole: Wydawnictwo Uniwersytetu Opolskiego.

Jenkins, H. (2006). Kultura konwergencji. Zderzenie starych i nowych mediów. Grudzień: Wydawnictwa Akademickie i Profesjonalne.

Livingstone, S. M., \& Bovill, M. (2001). Children and their changing media environment: A European comparative study. Mahwah, N.J: L. Erlbaum.

Manovich, L. (2006). Język nowych mediów, series: >Cyberkultura - Internet - Społeczeństwo<, Warszawa: WAiP. ISBN 978-83-60501-02-3.

Reis, F. (2007). e-Government 2004: Internet Based Interaction with European Businesses and Citizens, EuroStat, European Communities, 25 / 2005 - I quote the data [after:]

Serdyński, A. (2007). Kompetencje informatyczno-medialne nauczyciela, series: > Rozprawy i Studia<, vol. [DCCII] 628, Szczecin: Wydawnictwo Naukowe Uniwersytetu Szczecińskiego.

Sysło, M. M. Model rozwoju kompetencji informatycznych. In Informatyka w Szkole XX. Wrocław, 06-09.09.2004 [accessed on: 21 September 2010].

\section{Contact:}

dr Mateusz Muchacki

Uniwersytet Pedagogiczny im. KEN w Krakowie

Ul.Podchorążych 2, Kraków, Polska

e-mail address: mattim@inf.ap.krakow.pl 